\title{
Optimization of fermenters for ethanol production: residence time analysis applying computational fluid dynamics
}

\section{Otimização de fermentadores aplicados na produção de etanol: análise tempo de residência utilizando fluidodinâmica computacional}

\author{
Evelise Roman Corbalan Gois Freire ${ }^{1}$; Paulo Seleghim Júnior ${ }^{2}$
}

\begin{abstract}
The search for new ways to provide fuel for the society is a great challenge for scientists. An interesting alternative to petroleum-derived fuels is the ethanol produced from sugar cane. Brazil has an advantaged position in ethanol production, but the equipment used in the sugar cane plants, the fermenters, for example, still need efficiency improvements. The fermenter geometry has a great influence on the flow parameters and, consequently, in the chemical reactions involved in the fermentation process. It is necessary to ensure that the sugar cane juice remains enough time in the fermenter to complete the chemical reaction, but not more than the ideal time required, which can reduce the process efficiency. In this study, the influence of the geometry in the Residence Time Distribution (RTD) was analyzed by a computational tracer injection technique. Besides, twenty geometries were performed applying a univariate optimization process. Results show the inlet angle has the major influence in the flow and the optimum geometry for the continuous fermenter must have $22.5^{\circ}$ for inlet angle and $120 \mathrm{~cm}$ for outlet tube height. Considering the fermenters large scales in sugarcane juice processing, the improvement proposed in the fermenter geometry can increase its efficiency and reduce environmental impacts.
\end{abstract}

Keywords: Residence time distributions. Computational fluid dynamics. Fermenters. Ethanol production.

\section{Resumo}

A procura por novas formas de garantir combustível para a sociedade é um grande desafio para cientistas. Uma alternativa interessante ao combustível derivado do petróleo é o etanol produzido a partir da cana-deaçúcar. Apesar do Brasil estar em condições de vantagem na produção de etanol, os equipamentos utilizados na usinas sucroalcooleiras, como os fermentadores por exemplo, ainda necessitam de melhorias em sua eficiência. A geometria do tanque do fermentador tem uma grande influência nos parâmetros do escoamento interno, e consequentemente, afetam fortemente as reações químicas envolvidas no processo. Para melhor eficiência do equipamento, é preciso garantir que o mosto permaneça o tempo adequado dentro do tanque para que as reações químicas sejam completadas. Caso permaneça um tempo maior que o exigido, as reações químicas são prejudicadas. Neste estudo, a influência da geometria do tanque do fermentador na distribuição de tempo de residência (DTR) foi avaliada através da simulação computacional da injeção de um traçador no escoamento. Além disso, vinte geometrias foram simuladas através de um processo de otimização univariada. Resultados mostram que o ângulo entre a tubulação de entrada do tanque é o parâmetro geométrico com maior influência no escoamento. A geometria que garante o ângulo de escoamento ideal deve ter $22,5^{\circ}$ de ângulo de entrada, combinada com uma altura de $120 \mathrm{~cm}$ para a tubulação de saída. Considerando que os fermentadores são utilizados em processamento de alta escala, as melhorias propostas na geometria do fermentador podem aumentar sua eficiência e reduzir impacto ambiental.

Palavras-chave: Distribuição de tempo de residência. Fluidodinâmica computacional. Fermentadores. Produção de etanol.

\footnotetext{
${ }^{1}$ Profa. Dra., Depto. Ciências Exatas, UFLA, Lavras, Minas Gerais, Brasil; E-mail: evelise.freire@ufla.br

${ }^{2}$ Prof. Tit., Escola de Engenharia de São Carlos, USP, São Carlos, SP, Brasil; E-mail: seleghim @ sc.usp.br
} 


\section{Introduction}

Different forms of bioenergy have been used by humans since early times. With the evolutionary process of humankind and the emergence of new technologies, wood was replaced by coal as a means to produce energy. The bioenergy produced using wood as primary biomass was replaced by non-renewable resources such as coal, and later, oil and natural gas. The trend of the extinction of fossilized solar energy has brought up an urgent need to seek new ways of producing photosynthetic energy (CORTES et al., 2018). It is necessary to search alternatives to continue modern industrial evolution, providing a sustainable energy context (NOGUEIRA, 2008). Thus, the ethanol it is valuable resource.

Ethanol can be produced from every biomass with enough sugar or starch concentration. For example, it is possible to use sugarcane, cassava, wheat, sugar beet, etc. Brazil has an advantaged position in ethanol production from sugarcane. The 2018/2019 harvest produced 72.231 $\mathrm{kg} / \mathrm{ha} 625$ billion tons of sugarcane, resulting in 33.14 billion liters of ethanol.

Ethanol is produced by sugarcane juice fermentation process (first generation ethanol). The process results in vinasse and bagasse. Bagasse is usually burned to feed the boilers and generate electricity. However, new techniques to obtain ethanol from bagasse (second generation ethanol or cellulosic ethanol) have been studied (DIAS et al., 2011). Thus, the predominant way to obtain ethanol from sugarcane is the fermentation process.

Considering the continuous fermentation process, the microorganisms are maintained inside the fermenter and the substrate is circulated continuously. This process does not require microorganisms adaptation, resulting in the maximum cell growth.

In Brazil, between $25 \%$ and $30 \%$ of the sugarcane ethanol production plants are using the continuous fermentation process. The chemical reactions involved in the fermentation process can be influenced by several flow parameters, such as residence time distribution (RTD), mass transfer, shear stress, mixing, control of $\mathrm{PH}$, temperature and substrate conditions (XIA et al., 2008).

Due to the large scales production, any process efficiency improvement can result in a very significant overall optimization in terms of production rates and environmental impacts as well. Considering a sugarcane ethanol production plant processing 2 million tons of sugarcane per harvest, just $1 \%$ of improvement increases the productivity by 1.8 million liters of ethanol (BOSCO, 2006).
Thus, improve the fermentation process is a challenging issue for engineering research that can bring a very significant impact, also reducing the environmental impact caused by process production.

The greatest challenge to study this kind of bioreactor is the large scales of processing, which is of the order of 45 thousand liters per hour. The fermenter design has a significant influence on the flow conditions, with respect to residence time, mass transfer, shear stress, mixing, control of $\mathrm{pH}$, temperature and substrate conditions (XIA et al., 2008). The residence time of the fluid in the fermenter directly affects the equipment efficiency. Thus, it is very important to determine the adequate residence time inside a bioreactor used in the ethanol production.

Both higher and smaller residence times can be prejudicial to the required chemical reactions. If bagasse remains inside the bioreactor less than necessary, the biochemical reaction will not be completed. On the other hand, if the bagasse stays more than the indicated residence time, the biomass will have lost important properties, and the ethanol production will be impaired.

Due to the difficulty to perform experimental analysis, the expensive materials that are used and the time limitations, Computational Fluid Dynamics (CFD) tools are a useful alternative to study the flow inside reactors and bioreactors. This kind of analysis contributes to better define their design principles.

Several studies have attempted to measure the residence time distribution in bioreactors, including bioreactors with impellers. In Davidson et al. (2003), CFD was applied to characterize the circulation time distribution in three different stirred tanks (DAVIDSON et al., 2003). Tracer particles were simulated for 30s. Considering 5000 particles, computational simulations provided more accuracy than the experimental results. With CFD tools it was possible to count 9053 circulations against 1000 in the experimental results, providing more conclusive results. Also, the RTD analysis was applied in Choi et al. (2004) in order to determine the ideal behavior of a stirred reactor (CHOI et al., 2004). For low impeller rotations per minute values, the mean and the variance of residence time distribution deviate from ideal values. High impeller rpm contributed better agreements between ideal and evaluated RTD. The software prediction was inaccurate when the impeller was in the steady state.

In Patwardhan et al. (2005), CFD and experimental techniques was applied in order to analyze the influence geometry and operating conditions in the performance of a gas-liquid stirred reactor (PATWARDHAN et al., 
2005). The RTD was measured experimentally applying a giving radiotracer pulse. CFD predictions were in good agreement with the experimental measurements. Thus, the CFD model predictions of velocities could be considered closely representing the real flow patterns at the reactor.

Multistage agitated contactor with impellers was the focus of the study performed in Zhang et al. (2007) (ZHANG; PAN; REMPEL, 2007). This study also performed RTD analysis. They concluded that a cascade of stirred tanks with a back flow model is more suitable do describe the flow behavior in the reactor. The RTD curves obtained computationally were in good agreement with experimental data, but the $\mathrm{k}-\varepsilon$ model was not suitable to capture the turbulence the dumping effect in the reactor.

In the study of Ding et al. (2010), CFD tracer technique was applied in order to optimize the impeller design of a laboratory-scale continuous stirred-tank reactor (DING et al., 2010). The achieving a good agreement with experimental tests when decreasing the impeller velocity required. Using a different approach, other studies were based in a circulation time distribution (CTD) analysis. In one such study, Davidson et al. (2003) defined the residence time between consecutive passages of a particular cell through the nutrient of oxygen rich zones. The geometry considered was stirred tanks. For single phase cases, an experimental RTD analysis of liquid phase was performed in a concentric-tube airlift reactor in Gravilescu (1999). The classical pulse-response analysis contributed to improve the reactor performance and revealed that the investigated airlift reactor had more uniform flow than a tubular and bubble column.

Another kind of reactor applications is the anode flow bed analysis. In Sarris et al. (2006), the flow field and the residence times in an anode flow bed of a pilot direct ethanol fuel cell were studied. In this case, a 3-D numerical flow modeling was performed (SARRIS et al., 2006). The goal of the bed design was increase the residence time, improving the ethanol transformation in hydrogen. The tracer injection method was applied to evaluate the DTR. The study revealed the influence of the inlet velocity. However, careful analysis of the residence times and the flow field was required, due the equipment's complexity.

The study goal reported in this paper was to take a first step toward the prediction geometry influence in the variance of the residence time distribution for a continuous fermenter. This kind of analysis can improve the process efficiency, reducing the ideality deviations. The study encompassed tests with a combination of four different inlet angles and five different heights of outlet tubes, resulting in twenty different performed geometries. The RTD was obtained by a tracer injection in the flow, followed by a concentration monitoring at the outlet flow.

\section{Material and Methods}

In order to simulate the flow inside the bioreactor, the commercial software Ansys CFX was adopted. The initial fermenter geometry was composed by a cylindrical reservoir, with inlet and outlet ducts. The tube diameter for flow entrance and exit are both $5 \mathrm{~cm}$, and the total reservoir volume was $900 \mathrm{~L}$. These dimensions were considered according to the requirements for ethanol sugar cane production in a bench scale. The reservoir height was $1.5 \mathrm{~m}$ and the initial outlet tube length was $1 \mathrm{~m}$. The design for initial structure is shown in Figure 1.

Figure 1 - Fermenter geometry performed in the simulations.

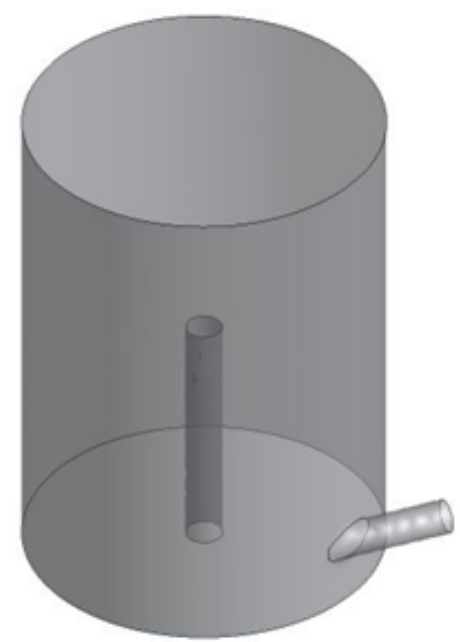

Source: The authors.

The governing equations were the Navier-Stokes equations, given by continuity and momentum equations:

$$
\begin{gathered}
\frac{\partial \rho}{\partial t}+\nabla \cdot(\rho U)=0 \\
\frac{\partial(\rho U)}{\partial t}+\nabla \cdot(\rho U X U)=-\nabla p+\nabla \tau+S N
\end{gathered}
$$

where $\tau$ is determined by

$$
\tau=\mu\left(\nabla U+(\nabla U)^{T}-\frac{2}{3} \delta \nabla \cdot U\right)
$$


The simulations were performed for a transient flow and the fluid was water. The simulation considered around ten minutes of flow, and the time step applied was 1 second. Steady flow results were used as an initial approximation, decreasing the computational cost. The flow was isothermal and incompressible. Turbulence effects were taken in account with the K- $\varepsilon$ model, which is more suitable for the flow inside a bioreactor, as can be observed in several related works (SARRIS et al., 2006; DING et al., 2010; CHOI et al., 2004).

The Navier-Stokes equations were solved using the finite volume method and the advection scheme was solved using high resolution method. As boundary conditions, considering the large scales applied in the ethanol production, the normal inlet flow velocity was $0.1 \mathrm{~m} / \mathrm{s}$ and the outlet pressure was $0 \mathrm{~Pa}$. The computational error was measured using RMS with $10^{-5}$ accuracy.

In order to obtain the residence time distribution, the stimulus-response method was applied. Analogously to the study performed in Le Moullec et al. (2008), a pulse of tracer is injected at the inlet and its concentration is monitored at the fermenter's outlet (LE MOULLEC et al., 2008).

The tracer was defined using a scalar additional variable. The tracer injection was defined as a boundary condition at the fermenter inlet through a pulse function defined by equation (4)

$$
1\left[\mathrm{kgm}^{-3}\right] \text { step }\left(\frac{1[\mathrm{~s}]-t}{1[\mathrm{~s}]}\right) .
$$

The step function defines an injection type pulse. The tracer implementation was performed at two steps in order to reduce the computational time.

At the first step a steady state simulation was performed, and in the second step the solution of the tracer transient transport equation was solved.

The mesh applied counted with 350000 tetrahedral elements and. This mesh can be seen in Figure 2.

In order to improve the simulations computational cost, a computational mesh efficiency comparison study was carried out. The test was performed using three different mesh configurations, as can be seen in Table 1 .

The flow was simulated for the proposed meshes, and a comparison of the velocity field obtained for each mesh was performed. The velocity field absolute error was evaluated considering Mesh 3 as a reference. Thus, the velocity fields obtained with the most refined mesh resulted in $84 \%$ of improvement.

Thereby, the best choice mesh for the simulations to obtain the residence time distributions was the finer mesh,
Figure 2 - Numerical mesh applied in this simulation.

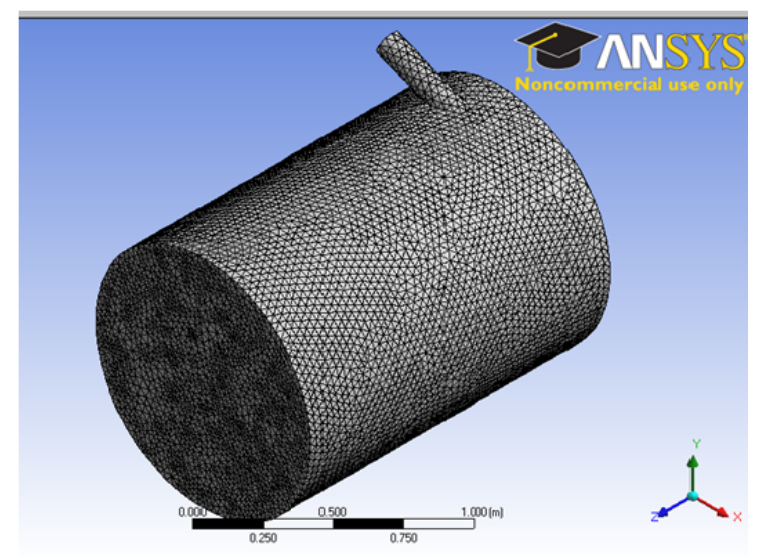

Source: The authors.

Table 1 - Comparison of computational mesh efficiency.

\begin{tabular}{ccc}
\hline & $\begin{array}{c}\text { Number of } \\
\text { elements }\end{array}$ & $\begin{array}{c}\text { Velocity field } \\
\text { absolute error }\end{array}$ \\
\hline Mesh 1 & 12000 & $84 \%$ \\
Mesh 2 & 62000 & $9 \%$ \\
Mesh 3 & 350000 & \\
\hline
\end{tabular}

Source: The authors.

shown in Figure 2. This mesh was composed of approximately 350 thousand elements and 60 thousand computational nodes. There was no mesh refinement in any specific region of the computational domain. This is justified considering that all regions were equally of interest in determining the occurrence of ideality deviations in the tank. In this study, diffentently from Romeiro et al. (2017), the non-sutructured mesh was applied.

The concentration curve $C(t)$ is a time function and was monitored at the fermenter outlet by a CFX monitoring point. Using the data from the $C(t)$ curve it is possible to determine the residence time function (or the exit-age distribution). The RTD curve describes, in a quantitative way, how much time different fluid portions remains inside the reactor (??). Residence time and variance values can be obtained using the equations (5) and (6)

$$
\begin{gathered}
t_{s} \cong \frac{\sum t_{i} C\left(t_{i}\right) \Delta t_{i}}{\sum C\left(t_{i}\right) \Delta t_{i}}, \\
\sigma^{2} \cong \frac{\sum\left(t_{i}-t_{s}\right) C\left(t_{i}\right) \Delta t_{i}}{\sum C\left(t_{i}\right) \Delta t_{i}} .
\end{gathered}
$$

In this study, the flow was performed for 20 different geometries, selected by a univariate optimization method. In this method, the parameters are fixed and one of them is 
assorted. At the second step, a new parameter was selected to be varied, fixing the others.

Through the qualitative analysis of the residence time distribution curves, it is possible to evaluate flow phenomena defined as deviations from ideality. Deviations from ideality were classified by Sassaki (2005) as follow short circuits and dead zones.

Short circuits are identified when the fluid remains for a short time inside the tank. When the opposite happens (fluid portions remains more than necessary inside the fermenter), the phenomena is called dead zone. It is possible identify short circuits and dead zones performing a RTD curve qualitative analysis (SASSAKI, 2005).

The occurrence of a short circuit indicates deficiency in the design and decreases the efficiency of the device. The occurrence of dead zones can jeopardize the fermentation process, precluding the chemical fermentation process from being completed.

\section{Results and Discussion}

Using a computational monitoring point at the outlet flow, it was possible to export a file from the CFX containing the data of tracer concentration. From these data, the residence time distribution and variance were evaluated applying the equations (5) and (6).

Thus, a total of 20 different geometries were tested. In order to choose the range of geometries, a univariate optimization was applied. Two geometry parameters modifications were studied: the angle $\alpha$ between the inlet tube and the tank fermenter, and the outlet height $h$ in the tube. The inlet angles tested were $\alpha=22.5^{\circ}$, $45^{\circ}, 67.5^{\circ}$ and $90^{\circ}$. The values of outlet height were adopted as $h=30 \mathrm{~cm}, 52.5 \mathrm{~cm}, 75 \mathrm{~cm}, 97.5 \mathrm{~cm}$ and $120 \mathrm{~cm}$.

Considering the qualitative analysis proposed in Sassaki (2005), the residence time distributions curves were observed in order to identify short-circuits and dead zones.

Qualitatively, oscillations at the first times interval are the main feature in DTR curves in the case of short circuit existence. Dead zones are characterized by high tracer concentrations at the final time interval (FOGLER, 2009).

Figure 3 shows the RTD variance for the tested flow geometries simulated.

Considering the variance analysis, the optimal and the worst geometry was both for $h=120 \mathrm{~cm}$. The optimal geometry, in other words, the one that provides the smallest variance in residence time distribution, is the one that has inlet angle $\alpha=22.5^{\circ}$.
Figure 3 - Residence Time Distribution variance for tested height outlet tube.

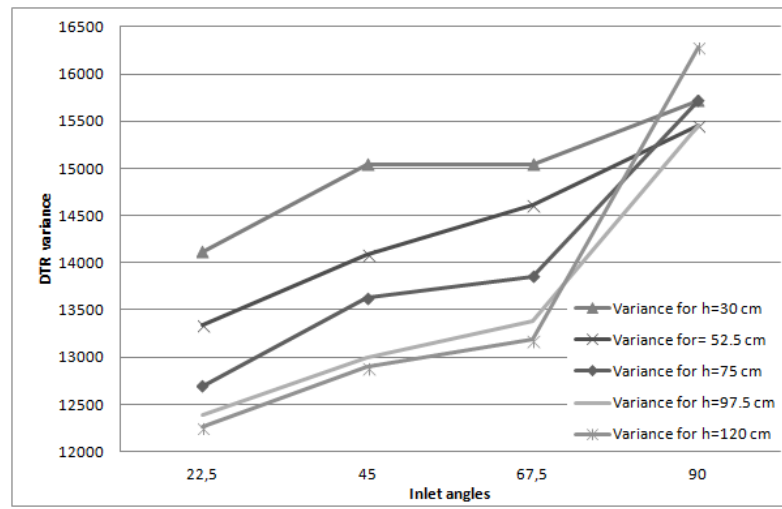

Source: The authors.

The geometry which the larger value for RTD variance has inlet angle $\alpha=90^{\circ}$, the perpendicular angle. It is interesting to notice that all the tested cases presented the same RTD curve tendency.

The curves showed similar trends fixing the inlet angle and changing the outlet height tube. The RTD curves for $h=52.5,75,97.5$ and $120 \mathrm{~cm}$ and $\alpha=22.5^{\circ}$ are presented in Figure 4. Oscillations in the first time interval for $h=30 \mathrm{~cm}$ and $h=52.5 \mathrm{~cm}$ denotes the short circuits occurrence. Thus, it is possible eliminate the short circuits occurrence increasing the $h$ values.

Figure 4 - RTD curves for $\alpha=22.5^{\circ}$ and the outlet tubes heights simulated.

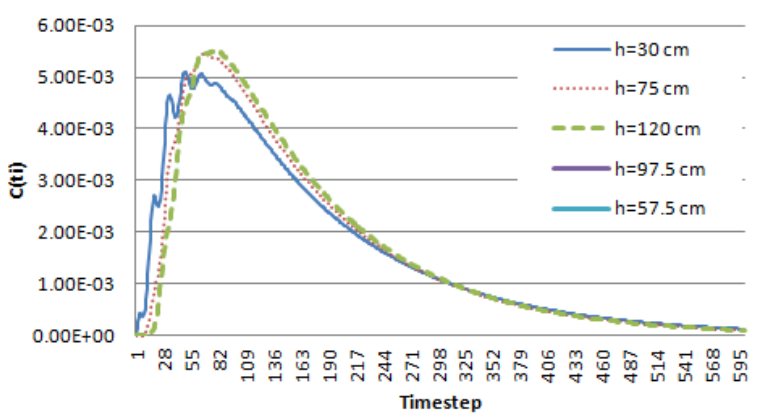

Source: The authors.

Figure 5 shows the RTD curve for $\alpha=45^{\circ}$. Smooth oscillations appear in the curve at the first times intervals for $h=30 \mathrm{~cm}$, characterizing short circuit in a part of fluid domain. In this case, short circuits does not happens when $\alpha=67.5^{\circ}$, as can be observed on Figure 6. Thus, it is possible to conclude that the outlet height variation does not affect the flow for this inlet angle. 
Figure 5 - RTD curves for $\alpha=45^{\circ}$ and the outlet tubes heights simulated.

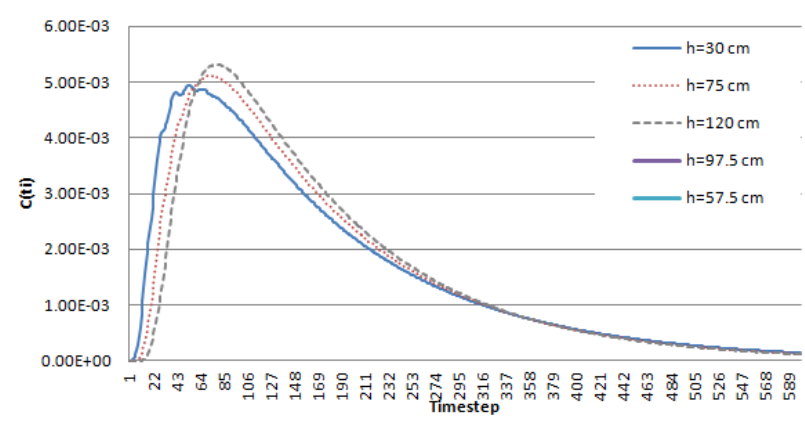

Source: The authors.

Figure 6 - RTD curves for $\alpha=67.5^{\circ}$ and the outlet tubes heights simulated.

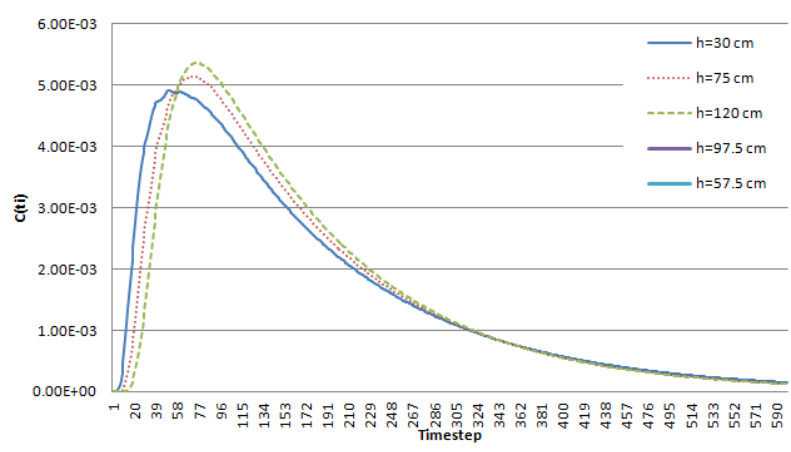

Source: The authors.

The RTD curves analyses showed that the angle was the parameter with greater influence at flow. The inlet angle influence for $h=120 \mathrm{~cm}$ can be observed in Figure 7 . Higher concentration at the last time interval are perceptible for $\alpha=67.5^{\circ}$ and $\alpha=22.5^{\circ}$ when compared at the same time step point. Thus, it follows that the perpendicular inlet angle cause the emergence of short circuit, but prevents the appearing of dead zones.

Figure 7 - RTD curves for $h=120 \mathrm{~cm}$ and four different inlet angles simulated.

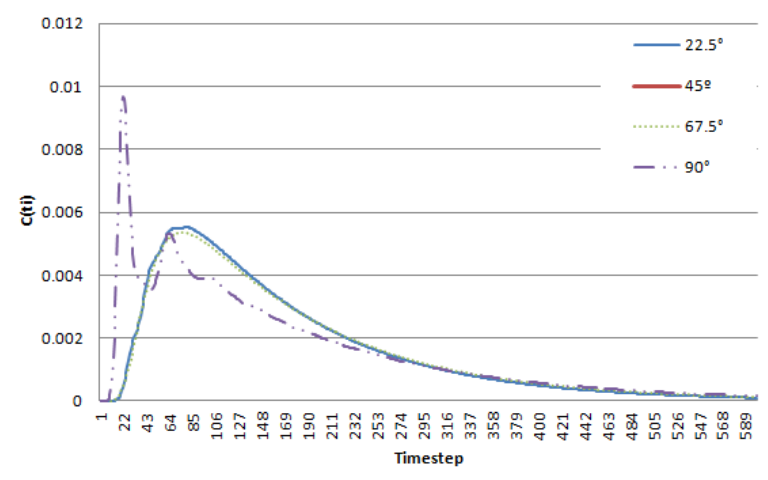

Source: The authors.
Observing, Figure 7, it is possible to notice the occurrence of an exponential decay behavior at long timescales. These results are in accordance with studies of Haringa $e t$ al. (2016) (HARINGA et al., 2016 ).

The study carried out by Gonçalves et al. (2019) related the RTD curve behavior with its variance in fermentative processes (GONÇALVES et al., 2019). They related the RTD curve long tails with high variance values. In agreement with Gonçalves et al. (2019), the results shown in Figure 3 and Figure 7 consider $h=120 \mathrm{~cm}$ and $\alpha=90^{\circ}$ the geometry with major variance taxes. The RTD curve in Figure 7 presents the longest curve tail.

The RTD curve for $\alpha=90^{\circ}$ inlet angle represented in Figure 7 present two apices for the initial times. As studied in Gonçalves et al. (2019), these apices ocurrences shows that the equipment in this configuration has a higher number of dead zones. This is a deviation ideality condition for a fermenter, with can be confirmed by streamlines analysis.

Figure 8 shows the streamlines for the optimal and the worst geometry obtained for the continuous fermenter in this study. It is possible to observe how the streamlines are sensible to inlet angle modifications. The streamlines for perpendicular angle presented an unequal behavior, causing the appearance of short circuits, as identified by the qualitative analysis of residence time distributions.

Figure 8 - Qualitative analysis of RTD curves: $h=120 \mathrm{~cm}$ with $\alpha=90^{\circ}$ (Left) and $\alpha=22.5^{\circ}$ (Right).
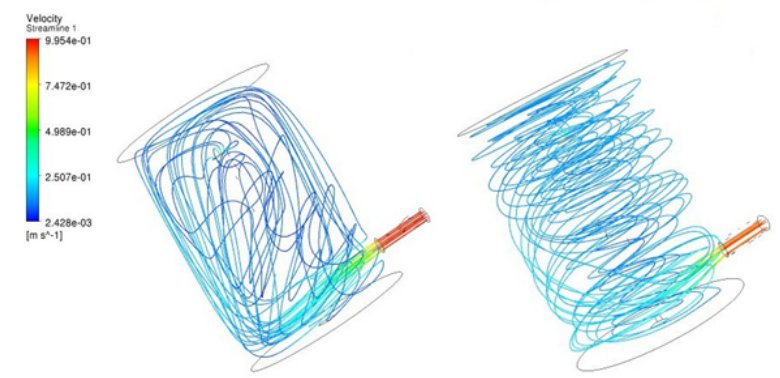

Source: The authors.

The optimal geometry for $\alpha=22.5^{\circ}$ presented a more coordinated flow than the perpendicular inlet, confirming again the RTD qualitative analysis. The results in Figure 8 are in agreement with the study developed by Ansoni and Seleghim (2016), where the simulations showed that short circuit effects are more evident in geometries with $90^{\circ}$ inlets angle (ANSONI; SELEGHIM, 2016). 


\section{Conclusion}

The aim of this study was to optimize the flow parameters in a continuous fermenter for ethanol production using Computational Fluid Dynamics. The optimization was performed by geometry modification applying a univariate optimization method. Twenty geometries were proposed. The variance of Residence Time Distribution (RTD) in the flow was evaluated by a computational tracer injection methodology.

The results reported here propose a continuous fermenter with specific dimensions, ensuring that the smallest value of variance of RTD is obtained. The occurrence of deviations of ideality, namely dead zones and short circuits, were analyzed. The simulations results showed that the optimal geometry must have inlet flow angle $\alpha=22.5^{\circ}$ and outlet flow height tube $h=120 \mathrm{~cm}$. This was the smallest inlet angle tested, considering angles smaller than $20^{\circ}$ can make welding in real equipment difficult.

Considering the big scales applied in the ethanol from sugarcane process, a small improvement in the fermenter performance can cause major impacts in terms of profit and reduction of environmental impacts. This study is able to contribute as a first step for a scale-up analysis.

\section{Acknowledgments}

This research was supported by National Council for Scientific and Technological Development, CNPq.

\section{References}

ANSONI, J. L.; SELEGHIM, P. Jr. Optimal industrial reactor design: development of a multiobjective optimization method based on a posteriori performance parameters calculated from CFD flow solutions. $A d-$ vances in Engineering Software. 91:23-35, 2016. DOI: https://doi.org/10.1016/j.advengsoft.2015.08.008.

BOSCO, F., Busca pela vanguarda, Alcoolbras, Edição $\mathrm{n}^{\mathrm{o}}$ 102, <https://www.revistaalcoolbras.com.br"> Accessed: December, 2019

CHOI, B. S., et al. Residence Time Distributions in a Stirred Tank: Comparison of CFD Predictions with Experiment. Industrial \& Engineering Chemistry Research 43(20): 6548-6556, 2004. DOI: https://doi.org/10.1021/ie0308240.
CORTES, S. L., et al., Optimisation of fermentation conditions in the production of ethanol from Palmer mango. Semina: Ciências Exatas e Tecnológicas, Londrina, v. 39, n. 1, p. 34-41, 2018. DOI: https://doi.org /10.5433/16790375.2018v39n1p34

DAVIDSON, K. M., et al., Using Computational Fluid Dynamics Software to Estimate Circulation Time Distributions in Bioreactors. Biotechnology Progress. 19: 14801486, 2003. DOI: https://doi.org/10.1021/bp025580d

DIAS, M., et al., Simulation of integrated first and second generation ethanol production from sugarcane: comparison between different biomass pretreatment methods. Journal of Industrial Microbiology \& Biotechnology 38(8): 955-966, 2011. DOI: https://doi.org/10.1007/s10295-010-0867-6

DING, J., et al., CFD optimization of continuous stirred-tank (CSTR) reactor for biohydrogen production. Bioresource Technology 101(18): 7005-7013, 2010. DOI: https://doi.org/10.1016/j.biortech.2010.03.146

FOGLER, H. S. Elementos de Engenharia das Reações Químicas, 4ª . Ed. Rio de Janeiro: LTC, 2009.

GAVRILESCU, M.; TUDOSE, R. Z. Residence time distribution of the liquid phase in a concentric-tube airlift reactor. Chemical Engineering and Processing: Process Intensification 38(3): 225-238, 1999. DOI: https://doi.org/10.1016/S0255-2701(99)00005-7

GONÇALVES, T. A. C., et al., Estudo da distribuição do tempo de residência em um reator contínuo de tanque agitado. Brazilian Journal of Development 5(10): 1777917784, 2019. DOI: https://doi.org/10.34117/bjdv5n10-046

HARINGA, C., et al., Euler-Lagrange computational fluid dynamics for (bio)reactor scale down: An analysis of organism lifelines. Engineering in life Sciences. 16, 652-663, 2016. DOI: https://doi.org/10.1002/elsc.201600061

LE MOULLEC, Y., et al., Flow field and residence time distribution simulation of a cross-flow gas-liquid wastewater treatment reactor using CFD. Chemical Engineering Science 63(9): 2436-2449, 2008. DOI: https://doi.org/10.1016/j.ces.2008.01.029

NOGUEIRA, L. A. H. Bioetanol de Cana-de-açúcar. Energia para o desenvolvimento sustentável. Rio de Janeiro: BNDES e CGCE, 2008. 316p. 
PATWARDHAN, A. W., et al., Optimization of gas-liquid reactor using computational fluid dynamics. Chemical Engineering Science 60(11): 30813089, 2005. DOI: https://dx.doi.org/10.1590/0104$6632.20190364 \mathrm{~s} 20180450$

ROMEIRO, N. M. L., et al., Numerical simulation of BOD5 dynamics in Igapó I lake, Londrina, Paraná, Brazil: Experimental measurement and mathematical modeling. Semina: Ciências Exatas e Tecnológicas, Londrina, v. 38, n. 2, p. 50-58, 2017. DOI: http://doi.org/10.5433/1679$0375.2017 \mathrm{v} 38 \mathrm{n} 2 \mathrm{p} 50$

SARRIS, I., et al., A three-dimensional CFD model of direct ethanol fuel cells: Anode flow bed analysis. Solid State Ionics 177(19-25): 2133-2138, 2006. DOI: https://doi.org/10.1016/j.ssi.2006.02.019
SASSAKI, R. A. Distribuição de Tempos de Residência em Sistemas Alimentados com Vazão Variável. 100 pp. (Mestrado). Universidade Federal do Rio de Janeiro, Rio de Janeiro, 2005.

XIA, J.Y., WANG, S.J., ZHANG, S. L., ZHONG, J. J., Computational investigation of fluid dynamics in a recently developed centrifugal impeller bioreactor. Biochemical Engineering Journal 38(3): 406-413, 2008. DOI: https://doi.org/10.1016/j.bej.2007.08.006

ZHANG, L., PAN, Q., REMPEL, G. Residence Time Distribution in a Multistage Agitated Contactor with Newtonian Fluids: CFD Prediction and Experimental Validation. Industrial \& Engineering Chemistry Research 46(11): 3538-3546, 2007. DOI: https://doi.org/10.1021/ie060567+ 